\title{
Guds børn og Fadervor (I):
}

\section{Dåbsritualets led og rækkefølge ifølge N.F.S. Grundtvig ${ }^{1}$}

\author{
Lektor, dr.theol. \\ Nils Arne Pedersen, Aarhus Universitet
}

\begin{abstract}
In the baptismal ritual of the Church of Denmark, the Lord's Prayer has since 1912 been placed after baptism while it formerly was placed before, as in Luther's Taufbüchlein. Two consecutive articles argue that the replacement in 1912 was influenced by the theology of Nikolai Frederik Severin Grundtvig. The current first article deals with Grundtvig's understanding of baptism as a sacrament, and his view and criticism of the baptismal ritual of his time.
\end{abstract}

Key Words: N.F.S. Grundtvig - Baptism - Ritual - Lord's Prayer Children of God

\section{Indledning}

Anledningen til denne undersøgelse er den debat, der i de senere år er blevet ført i folkekirken om takkebønnen i indledningen til folkekirkens dåbsritual: "Vi takker dig, himmelske Fader, fordi du ved din enbårne Søn har givet os den hellige dåb, hvori du gør os til dine børn og skænker os Helligånden med syndernes forladelse og det evige liv." Sætningen, "hvori du gør os til dine børn", der blev indført i ritualet i 1912, er blevet kritiseret ud fra det synspunkt, at "alle skabninger er Guds børn", og den er blevet forsvaret med henvisning til den kristne lære om arvesynden. ${ }^{2}$ Denne diskussion er heller ikke irrelevant, for

1. Det havde ikke været muligt at skrive dette arbejde uden en afgørende hjælp og støtte fra min bror, lic.theol. Kim Arne Pedersen, for hvilken jeg takker hjerteligt. Ligeledes takker jeg provst em. Holger Villadsen for hjælp og oplysninger vedr. vigtige liturgihistoriske forhold. - I det følgende benyttes disse forkortelser: GSV = N.F.S. Grundtvig, Sang-Vark til den danske Kirke, 1-5 (København: G.E.C. Gad 1982-1984); US = N.F.S. Grundtvigs Udvalgte Skrifter ved Holger Begtrup, I-X (København: Gyldendal 1904-1909); VU = N.F.S. Grundtvig, Varker i Udvalg ved Georg Christensen og Hal Koch, I-X (København: Gyldendal 1940-1949).

2. Se fx Holger Lissner, Kollekter og bønner (Frederiksberg: Aros Forlag 2009, $\left.{ }^{3} 2013\right), 215-216$; Carl Lomholt, "Dåben som adgangsbetingelse - eller som ubetinget nåde”, Presteforeningens Blad 22-23 (2014), 552-554; Thomas Felter, Dåbens teologi og praksis $i$ historisk og aktuel belysning, Fleksibel Masteropgave (Det Teologiske Fakultet, Københavns Universitet, september 2014); diverse indlæg i Kristeligt 
der er ingen tvivl om, at sætningen forudsætter, at mennesket ikke er et Guds barn forud for dåben, og at den således peger på læren om syndefaldet som begrundelse for dåbens nødvendighed. Baggrunden for, at netop denne sætning blev indført i ritualet, har imidlertid næsten ikke været berørt af stridens parter. Det skete imidlertid i nøje sammenhæng med, at dåbsritualet fra 1912 flyttede Fadervor hen efter dåben, som det fremgår af en bemærkning i biskoppernes fortale til Forslag til Ritualer for Daab, Nadvere, Brudevielse og Begravelse (København: Det kgl. Vaisenhuses Forlag 1910), 7: "Endelig er Fadervor flyttet hen efter Daaben; derved udtrykkes det, at den døbte nu er optaget blandt dem, der har Ret til at bede Guds Børns Bøn, og indlemmet i Samfundet af dem, med og for hvem Fadervor bedes." Den teologihistoriske baggrund for takkebønnen og Fadervors ændrede placering er således af aktuel relevans.

Det nye dåbsritual var formuleret af Sjællands biskop Peder Madsen (1843-1911) og fremlagt for hans kolleger ved bispemødet den 23.-25. februar 1910. ${ }^{3}$ Emnet for nærværende undersøgelse er dog ikke 1912-dåbsritualet som sådan, men kun spørgsmålet om oprindelsen til sætningen om Guds børn og flytningen af Fadervor. Siden 1556 havde Fadervor efter mønster fra Luthers Taufbüchlein været placeret før selve dåben, lige efter oplæsningen af Mark 10,13-16 om Jesu velsignelse af de små børn, således også i revisionerne af dåbsritualet fra 1685, 1783 og 1895. ${ }^{4}$ Forskningen har hele tiden været opmærksom på, at biskopperne med flytningen imødekom et ønske, der længe var blevet fremsat af grundtvigianerne. Flytningen af Fadervor blev da også anmeldt positivt i Dansk Kirketidende af den grundtvigske præst, senere biskop Christian Ludwigs (1877-1930) og i Højskolebladet af valgmenighedspræst Asger Højmark (1865-1944). ${ }^{5}$ Det

Dagblad fra sommeren 2018 (fx Mette Skov Hansen 12/6, 8; Jens Ole Christensen 30/6, 9; Christiane Gammeltoft-Hansen, 7/7, 8; Hans Raun Iversen, 19/7, 4; HansOle Bækgaard, 24/7, 8); Agnete Raahauge, "Dåbsforfølgerne i Lindevang kirke”, Tidehverv 6 (2018), 101-103; Dåb og nadver. Om sakramenterne i Den danske Folkekirke. Rapport fra Fagudvalget vedrorende dåb og nadver (maj 2019), passim.

3. Se Christian Thodberg, "Dåbsritualets historie", Dåb og brudevielse. Betenkning afgivet af Kirkeministeriets liturgiske kommission. Betænkning nr. 973 (København 1983), 37-38; ligeledes Thodbergs store upublicerede “dåbskompendium”, der blev brugt ved undervisningen på Aarhus Universitet, Dåben og dåbsritualets historie (Efteråret 1999), 209-211; det blev for få år siden publiceret i forkortet form: idem, Dåben og dåbsritualets historie, red. Kristoffer Garne \& Peter Thyssen, Palmeserien 2 (København: Fønix 2017), 182-185.

4. Der foreligger i øvrigt en uhyre nyttig oversigt over de officielle danske dåbsritualer fra 1556 til i dag på Villadsens hjemmeside, til hvilken læseren kan henvises: http://www.sejrupvilladsen.dk/LN-15.pdf (besøgt 15.05.20).

5. P.G. Lindhardt, Den danske kirkes historie VIII (København: Gyldendalske Boghandel \& Nordisk Forlag 1966), 46; Thodberg (1983), 32-37, 39; idem (1999), 213 
lader sig da også forbinde med et forslag til en ny alterbog, som den grundtvigske præst Peter Andreas Fenger havde publiceret i 1874; også her var Fadervor placeret efter dåben. Dette forslag var ifølge Fenger udarbejdet sammen med hans "faderlige Ven" Nikolai Frederik Severin Grundtvig. ${ }^{6}$

Ikke desto mindre har Christian Thodberg vedholdende argumenteret for, at "flytningen af Fadervor" i 1912 ikke var en konsekvens af Grundtvigs dåbsteologi, ja tværtimod. Dermed må det siges at være uklart, hvor grundtvigianernes ønske om at flytte Fadervor egentlig kom fra, og der må således siges at være brug for to undersøgelser - for det første en undersøgelse af Fadervors rolle og placering ved dåben ifølge Grundtvig og på baggrund heraf for det andet en undersøgelse af dåbsritualet i Fengers alterbogsforslag. Nærværende dobbeltartikel bringer dog kun undersøgelsen af Grundtvigs syn på Fadervor i forbindelse med dåben, men jeg forbereder også en undersøgelse af dåbsritualet i Fengers alterbogsforslag.

Det givne dåbsrituals led og rækkefølge og Grundtvigs syn på det er en væsentlig kontekst for at forstå Grundtvigs tanker om Fadervor ved dåben. Thodbergs argumentation synes nemlig at rejse to spørgsmål: Regnede Grundtvig ikke med et sakramentalt centrum i vandoverøsningen og døbeordene, og var Grundtvig "bundet" til sin samtids 1783-ritual? Disse spørgsmål vil så vidt muligt blive besvarede i denne første del af dobbeltartiklen om "Guds børn og Fadervor".

\section{Fadervor i dåbsritualets rækkefølge ifølge Christian Thodbergs Grundtvig-fortolkning}

Det var oprindeligt i sin En glemt dimension $i$ Grundtvigs salmer - bundetheden til dåbsritualet fra 1969, at Thodberg hævdede, at 1783-dåbsritualets rækkefølge af liturgiske led og dermed Fadervors placering før dåben var afgørende for Grundtvig, men senere blev disse fortolkninger videreført i artiklen i Kirkeministeriets betænk-

= idem (2017), 187; Ludwigs, "Biskoppernes Ritualforslag", Dansk Kirketidende 3 (1911), 34: "Der er her sket betydelige Fremskridt. Ikke mindst, at Fadervor er kommet paa sin rette Plads - efter Daaben"; Højmark, "Biskoppernes Forslag til ny Ritualer”, Højskolebladet (1911), 61: "Dernæst er Bekendelsen af Fadervor flyttet hen til efter Daaben, hvor den rettelig hører hjemme."

6. Forslag til en paany gjennemseet Alter-Bog, som kunde blive tilladt til Brug i den danske Folkekirke (Kjøbenhavn: Trykt i Thieles Bogtrykkeri for E.L. Thaarup 1874), 6-8, 27. 
ning fra 1983 og i det nævnte "dåbskompendium". ' Som titlen på Thodbergs bog fra 1969 angiver, beskæftigede bogen sig primært med Grundtvigs salmer, ud fra hvilke Thodberg søgte at påvise den nære sammenhæng mellem 1783-dåbsritualets led og dåbssynet:

Allerstørst betydning har dog nok ritualets disposition haft. Leddenes rækkefølge er for Grundtvig ikke tilfældig. I ritualet er der en stigning fra bønnen om at bede og banke på over Mark. 10, 13-17 og Fadervor til selve dåbshandlingen og fredslysningen. Særlig interessant og vigtig i dette forløb er sammenhængen mellem Mark. 10 og Fadervor. Leddenes rækkefølge er altså ligeså væsentlig som leddene i sig selv (Thodberg (1969), 13).

Thodberg påviste overbevisende,

at hvor Grundtvig i sine salmer nævner udtrykket favn eller tilsvarende udtryk (arme, hænder osv.), der henleder opmærksomheden på børneevangeliet, Mark. 10,13-17 - dær [sic] dukker Fadervor ofte op som et led, der er naturligt vævet ind i sammenhængen. Og omvendt. ${ }^{8}$

Thodberg ville videre understøtte denne tese ved at vise, at når Grundtvig i sine salmer satte Fadervor lig håbet, var det pga. det i ritualet "næsten umiddelbart følgende 1 Peter 1, 3" (Thodberg 1969, 79-83, citat 82) om genfødslen til et levende håb. Treheden tro, håb og kærlighed fra 1 Kor 13,13 var vigtig for Grundtvig, der satte troen lig med trosbekendelsen, Fadervor med håbet og nadveren med kærligheden, men Thodberg mente altså, at citatet fra 1 Pet 1,3 var den oprindelige årsag til, at Fadervor blev forstået som håbet. I Grundtvigs salmer spillede udtrykket "herlighedens Haab" fra Kol 1,27 også en stor rolle, men ritualet havde været Grundtvigs udgangspunkt: "Selv trilogien tro/håb/kærlighed og herlighedens håb fra Kol. 1,27

7. En glemt dimension i Grundtvigs salmer - bundetheden til dåbsritualet (København: G.E.C. Gad 1969), passim; også genoptrykt i idem, Syn og sang: Poesi og teologi hos Grundtvig (København: G.E.C. Gad 1989), 7-119; Thodberg (1983); samt idem (1999) = idem (2017). - 1783-ritualet citeres i dette arbejde fra Forordnet Alter-Bog udi Dannemark og Norge, hvori findes de nyelig allenaadigst giorte Forbedringer (Kiøbenhavn: Den Gyldendalske Boghandlings Forlag 1812), 241-251 (herefter forkortet: Forordnet Alter-Bog (1812)), som Grundtvig i øvrigt selv var i besiddelse af, således som det fremgår af Fortegnelse over N. F. S. Grundtvigs Bibliothek, som bortsalges ved offentlig Auction i Kledeboderne Nr. 38 Mandagen den 29. Sept. 1873 Kl. 10 (Kjøbenhavn: E.C. Løsers Bog- og Nodetrykkeri 1873), 86 (nr. 2166).

8. Thodberg (1969), 48; hele undersøgelsen 39-73; videre idem (1983), 27; idem (1999), 149-152 = idem (2017), 146-149. 
må være sekundære i forhold til identifikationen Fadervor/håb fra ritualet" (Thodberg 1969, 83).

Thodberg drog meget vidtgående slutninger af disse undersøgelser:

For Grundtvig er rækkefølgen børneevangeliet-Fadervor altafgørende. Det er et billede, der inspirerer ham fra først til sidst. Det bliver den vision, der fastholder hans tanker livet igennem. Ja, man kan måske driste sig til at sige, at det bliver et så centralt led i hans kristendomsforståelse, at denne sammenhæng afgiver den bedste forklaring på hans selvfølgelige fastholdelse af barnedåben."

Det må siges at være en svaghed ved Thodbergs fortolkninger, både i bogen fra 1969 og i det senere "dåbskompendium", at de næsten kun bygger på Grundtvigs salmer. Hvis det er rigtigt, at selve rakkefolgen af led i 1783-ritualet er central i Grundtvigs kristendomsforståelse, burde det også kunne vises i prosateksterne, særligt i betragtning af, at Grundtvigs produktion af prosatekster var uhyre stor. ${ }^{10}$ Ellers kan Thodbergs ubetvivlelige resultater nemlig også fortolkes således, at rækkefølgen i ritualet ganske vist var en rig kilde til poetisk inspiration hos Grundtvig, men at teologiske hensyn og overvejelser samtidig kunne føre til, at han ville forandre i den samme rækkefølge.

Det må dog også siges, at Thodberg vil fremtvinge en rækkefølge, hvor den vitterligt ikke foreligger. Ifølge Thodberg knyttede Grundtvig Fadervor sammen med håbet pga. "det næsten umiddelbart følgende 1 Peter 1,3", men det vil jo sige, at 1 Pet 1,3 ikke fulgte umiddelbart efter Fadervor; imellem kom leddet "Gud bevare din Indgang og Udgang, fra nu og til evig Tid! Amen”, samt et spørgsmål om barnets navn. Der er altså ikke tale om en rækkefølge af led.

9. Thodberg (1969), 42. Se også ibid., 92: Fadervor får netop "sin mening og betydning for Grundtvig stående mellem favnen i børneevangeliet og håbet i 1. Peter 1, 3, ja, at det faktisk er den skruestik, der holder Fadervor fast."

10. Thodberg (1969), 56-57: "Såvidt jeg kan se, dækker Grundtvig i sin prosa gang på gang over sine egne teologiske motiver. Hans personlige opfattelse fjern fra al polemik møder vi i salmerne. Der er ikke tale om nogen modsætning mellem poesi og prosa, men derimod om en ny dimension. Grundtvigs binding til dåbsritualet træder f. eks. næsten udelukkende frem i salmerne. Som dogmatiker og apologet træffer vi ham på prædikestolen og i den teologiske debat. I salmerne konfronteres vi med Grundtvig på kirkebænken og i enrum.” Se også ibid., 11: Bogen er "i alt væsentligt bygget på salmerne og kun i enkelte tilfælde på Grundtvigs prosa. Uden at være meget fortrolig med Grundtvigs prosa vil jeg påstå, at Grundtvigs tankegang på prosa i forhold til salmerne repræsenterer en refleksion, en videreudvikling og rationalisering af den primære erkendelse - en refleksion, der ifølge sagens natur kommer til at lægge vægten et andet sted end det egentlige”. I Thodberg (1999), 30 år senere, er inddragelsen af prosatekster imidlertid fortsat stærkt begrænset. Sml. også idem (1983), 27-28. 
Når Thodberg mener, at Fadervors plads før selve dåben er vigtig, har det imidlertid også noget at gøre med de teologiske strømninger, der endnu var dominerende i midten af det 20. århundrede, da $E n$ glemt dimension i Grundtvigs salmer blev til. Begreber og vurderinger fra den dialektiske teologi i dens eksistensteologiske aftapning blev i udpræget grad benyttet til at fortolke Grundtvig. Thodberg talte $\mathrm{fx}$ $(1969,11)$ om "et ord, et tilsagn i særdeleshed ... selve ordets eller den liturgiske handlings personlige tiltale-karakter." Korstegnelsen er $(1969,25)$ i "gudstjenesten blevet et eksistentielt udtryk for Guds tiltale. Det er simpelthen karakteren af personlig tiltale, der gør et liturgisk moment til et ord eller en handling af Herren selv." Denne eksistensteologiske tilgang har en spiritualiserende, antisakramental tendens; alt skal helst baseres i forkyndelsen eller ordet. Grundtvig var ifølge Thodberg imod "kult", og endvidere tenderede Thodberg oprindeligt mod at bestemme "det sakramentale" som det "ydre":

Det kommer bl. a. frem i den måde, hvorpå Grundtvig skelner mellem synligt og usynligt i gudstjenesten. Trods megen traditionel religiøs sprogbrug forhindrer denne grundtvigske dialektik en religiøs sikkerhed i at forskanse sig i kulten, i gudstjenestens ydre side. Det synlige peger altid ind mod det usynlige. Alt i gudstjenesten afspejler Guds ords tiltale og troens svar. Det er gudstjenestens egentlige mål at bringe denne skjulte dialog frem. ${ }^{11}$

11. Thodberg (1969), 12. Thodberg kritiserede her Søren Holm, Mythe og kult i Grundtvigs salmedigtning (København: Nyt Nordisk Forlag 1955). Holm ville fortolke Grundtvig ved hjælp af den tids religionshistoriske og religionsfænomenologiske ideer om primitiv religion, hvor kulten opretholdt den kosmiske orden gennem en rituel gentagelse af myten. En af de faktorer, der havde været med til at fremkalde den dialektiske teologi, var netop, at religionshistoriske begreber var begyndt at trænge ind i teologien. Som sådan var Holms bog et oplagt modstykke til det, som Thodberg gerne ville udtrykke. Ifølge Thodberg førte Grundtvig et opgør med kulten, ligesom Luther. Det er imidlertid et spørgsmål, om både Holms og Thodbergs fortolkninger ikke var hentet fra en kontekst, der i særlig grad gjorde det vanskeligt at nærme sig Luthers og Grundtvigs forståelse af sakramenterne som virkelige nådemidler. - Se også Thodberg (1969), 27: Det synlige peger hen på det usynlige ... det synlige skal høres ...; ibid., 29: "Men han slipper alligevel aldrig spændingen mellem det synlige og det usynlige, mellem vores kirke og Guds kirke"; ibid., 60: Grundtvigs fromhed kunne man kalde sakramental, men sakramental "betyder uendeligt meget mere end ellers. Det sakramentale er mere end det ydre"; ibid., 60-61: i nadverlæren regnede Grundtvig kun med en realpræsens i ordet; ibid., 111. "Dåbsvandet spiller ikke samme rolle for Grundtvig som f. eks. for Luther. Hos Grundtvig får vandet udpræget ord-karakter”. I Thodberg (1999), 160 = idem (2017), 159, bruges betegnelsen "sakramental" imidlertid positivt og uden forbehold om Grundtvigs dåbssyn, men alligevel finder vi fortsat spiritualiseringen af Grundtvigs dåbssyn, se Thodberg (1999), 154-155 = idem (2017), 152. 
Det var typisk for tidens teologi at hævde, at tillid til sakramenterne som nådemidler er udtryk for "religion", en menneskelig søgen efter sikkerhed, og nedsættende knyttede man gerne religionshistorisk farvede begreber dertil som "kult", "magi" og "myte", eller man talte pejorativt om "kirkelighed", og således også hos Thodberg. ${ }^{12}$

Derfor er det vigtigt for Thodberg, at Fadervor i ritualet kommer før dåben. Når Luther anbragte Fadervor dér, bliver det nemlig af Thodberg fortolket som et udtryk for en fastholdelse af menneskets nød, fortvivlelse og henvisthed til Gud: "I modsætning til vort nuværende ritual bliver Fadervor anbragt i 'forgården' i den menneskelige nød og fortvivlelse som forbønnens mærke. Fadervor får dermed et meget stærkt sted i ritualet." ${ }^{13}$ Meningen synes at være, at 1912-ritualets placering af Fadervor efter dåben er udtryk for "religion", en sakramental sikring og forskansning i det ydre.

I forhold til påstanden i Fenger (1874) om, at Grundtvig stod bag hans forslag til dåbsritual, der flyttede Fadervor hen efter dåben, bemærker Thodberg: "Enten har Fenger misforstået Grundtvig. Han har i hvert fald næppe forstået salmerne, sådan som vi her har prøvet på det. Eller også har Grundtvig argumenteret imod sig selv på et andet plan end det, der var hans egentlige." 14 Denne ejendommelige åbenhed over for, at Grundtvig kunne have ment noget på et andet plan end det, som Thodberg mener var hans egentlige plan, skyldes, at Thodberg faktisk har fundet og fremlægger materiale, der taler mod hans egen tese; dette vidner om stor videnskabelig redelighed. Thodberg peger på, at Fadervor i salmen Op til Guds Huus vi gaae (GSV 5, No. 108) står efter trosbekendelsen og han tilføjer, at

12. Se videre Thodberg (1969), 21: Grundtvig var akultisk og mod magi; ibid., 98: "Nedfarten til dødsriget afmytologiseres altså ret kraftigt. Hovedsagen er, at dette led forstås som et evangelium, som en gave - som noget for den hjælpeløse tro"; ibid., 125: "ritualets ord lukkede ham ikke inde i en eller anden form for kirkelighed, men han tog dem så alvorligt, at de frigjorde ham som menneske."

13. Thodberg (1969), 41; jf. fx også ibid., 16, eller ibid., 107: "At Grundtvig specielt nævner gudsforladtheden, passer ind i det mønster, vi allerede kender fra Fadervor. Det er netop i gudsforladtheden, Jesu solidaritet med mennesket viser sig - i bønnen, der 'vil dø på læber kolde’.” Eller ibid., 108: Alle leddene før tilspørgslen i ritualet "taler om menneskelivets risikofyldthed med bønnen til Gud som fortegn. Det er menneskelivets vilkår, der tegnes.” Ibid., 125: "Med Fadervor bad den ængstede sig tilbage til den favn, hvori han engang blev lagt. Han blev barn igen. Han blev ikke overladt til sine egne sjælelige anstrengelsers muligheder, men blev fastholdt af det levende håb, af Kristus selv".

14. Thodberg (1969), 93-94. Senere foreslår Thodberg (1983), 34; idem (1999), 200 = idem (2017), 172, at Grundtvigs medvirken ved Fengers dåbsritual havde været mere begrænset; dette har dog intet grundlag i det, som Fenger selv anførte. 
“ $[t]$ alrige andre steder møder vi den samme leddeling om end ikke så prægnant." 15 Thodberg skriver endvidere:

Men argumenterer Grundtvig i salmerne virkelig for en flytning af Fadervor? Når han faktisk gør det i en række tilfælde, er han efter min mening bestemt af trilogien tro/håb/kærlighed og af Fadervor som det centrale i hans kristenliv - netop midt i dette liv som et kompas på sejladsen mellem dåben og Gudsbordet i himlen. I praksis har Fadervor først betydning efter dåben, dvs. i det bevidste liv. Men i ritualet at flytte Fadervor ned efter selve dåbshandlingen er en anden sag. ${ }^{16}$

Der er således tale om, at Thodberg ikke kan integrere sine iagttagelser i det helhedsbillede, som han forud havde dannet sig. Nye indsigter bør ellers normalt føre til en revision og et nyt billede. Her står de uformidlet ved siden af hinanden. Årsagen til, at Thodbergs fortolkning ikke kan ændres, er ikke helt let at se. En grund kunne muligvis være, at flytningen af Fadervor ville pege på selve overøsningen med vand sammen med døbeordene som ritualets centrum? Da Thodberg i nogle sammenhænge mener, at Grundtvig havde problemer med Luthers fremhævelse af, at dåben er ordet i forening med vandet, ${ }^{17}$

15. Thodberg (1969), 92-93 med 127 n. 28, der henviser til GSV 3, No. 89; 4, No. 164, 225; 5, No. 67, 72, 92, 147, 170, 199, 229. Ibid., 93 henviser også til GSV 1, No. 88:12. - I et senere arbejde, "Alt står i Guds Faderhånd og Op til Guds hus vi gå: Belyst ud fra forholdet mellem Grundtvigs prædikener og hans salmer i sommeren 1856" (oprindelig 1971), her citeret fra genoptrykket i Thodberg (1989), 135-136, anføres om Fadervors rolle: "Det lares altsaa [sic] i denne sammenhæng" - måske er Thodbergs tanke, at Fadervor i ritualet hører hjemme før dåben, men at det læres efter? Se også Thodberg (1983), 34.

16. Thodberg (1969), 94; jf. 41-42. Forbeholdet, at Grundtvig måske alligevel stod bag flytningen af Fadervor, genfindes også idem (1999), 199 n. 162 = idem (2017), 172 n. 108.

17. Thodberg (1969), 111: "Dåbsvandet spiller ikke samme rolle for Grundtvig som f. eks. for Luther. Hos Grundtvig får vandet udpræget ord-karakter”; idem (1999), 154 = idem (2017), 152: "Ligesom ved nadveren fik også ved dåben det materielle element, vandet, en lavere status, end det var tilfældet f.eks. hos Luther; ordet får prioriteten”. I de citater, som Thodberg her anfører som begrundelse, siger Grundtvig blot ikke mere end Luther: At vandet er intet, hvis det ikke er forenet med ordet. I artiklen "Var Grundtvigs nadversyn luthersk" (oprindelig 1975), her citeret fra genoptrykket i Thodberg (1989), 297, udtrykkes det mere nuanceret, men sagligt set på samme måde: Grundtvig "er også i overensstemmelse med luthersk lære, når det drejer sig om dåbsvandet, dåbens element, der - som Luther siger - er indfattet i ordet. Dåbens element kommer med andre ord ikke i vejen for den fremhævelse af dåbens ordkarakter, der er Grundtvigs anliggende ... Og han kommer i det store og hele ikke i konflikt med det lutherske syn overhovedet." - I et andet arbejde af Thodberg, "Den liturgiske eksegese og Grundtvig", Grundtvig Studier (2000), 121, hedder det: "Løsningen fandt Grundtvig i dåben - ikke i dåbens ydre handling, men i det lutherske dåbsrituals ord, som han opfattede som Guds ord til den enkel- 
kunne det for Thodbergs fortolkning udgøre en vanskelighed, at flytningen netop understreger forskellen på menneskets status før og efter dåben. En sådan betragtning er i hvert fald pedanteri for Thodberg: "En pedant vil sige: kun døbte kan bede Fadervor; det betyder, at Fadervor i dåbsritualet bør stå efter dåben i den treenige Guds navn. Først da har dåbsbarnet ret til det. Men det er og bliver en efterrationalisering, der ødelægger ritualet på et andet og dybere plan.”18

Thodbergs påstand om, at Grundtvig lagde mere vægt end Luther på dåbsordene frem for vandet, skal måske sammenholdes med, at "hele dåbens betydning" for Grundtvig ifølge Thodberg er at finde i hvert enkelt af ritualets led:

\begin{abstract}
Alle ord og udtryk i ritualet med personligt spørgende og tiltalende karakter bliver for ham i en kort form evangeliet eller "ordet”. Sådan havde han selv erfaret det. Forsøget på historisk og videnskabeligt at godtgøre, at disse bestemte ord hidrører fra Jesus selv, er i grunden sekundært. Hovedsagen er, at han har erfaret ritualordene som evangeliets eksistentielle tiltale ("Var Grundtvigs nadversyn luthersk", Thodberg (1989), 296-297).
\end{abstract}

Eller i "dåbskompendiet": "Hvert eneste led af ritualet (korsbetegnelsen, bede-banke-bønnen, Fadervor, døbeordene, 'Forsikkringen' (bønnen: 'Den almægtigste Gud...') og fredlysningen) rummer hver for sig hele dåbens betydning," ... (Thodberg (1999), $160=$ idem (2017), 159). - Denne antagelse giver jo mening ud fra det 20. århundredes Guds ord-teologi, hvor alle ordene bliver forstået som "tiltale", som "forkyndelse".

te." Det er tilsvarende velkendt, at Grundtvig ifølge Thodberg ikke fulgte Luthers sakramentlære i forbindelse med nadveren, men her blev kritiseret af Regin Prenter og Leif Grane: Thodberg, "Var Grundtvigs nadversyn luthersk", oprindelig 1975, også i Thodberg (1989), 296-324. Prenters indvendinger ("Gjorde Grundtvig op med den lutherske nadverlære?” Presteforeningens Blad 9 (1987), 153-168) blev besvaret af Thodberg ("Om Grundtvigs nadversyn", Presteforeningens Blad 41 (1987), 769-776) og hans elev Leif Kallesen ("Mere om Grundtvigs nadversyn”, Presteforeningens Blad 41 (1987), 776-784). Siden fulgte Granes kritik af Thodbergs fortolkning: "Grundtvigs nadversyn - og Luthers", Dansk Teologisk Tidsskrift (1999), 1-17; se også Svend Bjerg, Gud forst og sidst. Grundtvigs teologi - en lasning af Den christelige Børnelærdom (København: Forlaget ANIS 2002), 129-131.

18. Thodberg (1969), 93. Sml. idem (1983), 34; idem (1999), 199 = idem (2017), 171-172: "Når Fadervor flyttedes fra sin stærke plads i 'forbønnens forgård' efter Markus 10,13-16, skete det tydeligvis for at understrege 'børneretten': Kun den døbte har ret til at bede Fadervor, men det er og bliver et pedantisk udtryk for den grundtvigianske ortodoksi, at Fadervor i ritualet af den grund skal stå efter selve dåbsakten. Der er atter i dette tilfælde tale om 'den kristne sikkerhed', som dåben giver!" 
Thodbergs fortolkning er tænkt som et alternativ til Grundtvigs kirkelige anskuelse: "For os er anskuelsen, det vil først og fremmest sige teorien om den apostolske trosbekendelses historiske oprindelse, håbløst kompromitteret." I stedet søger han "Grundtvigs egentlige anliggende" i "selve ordets eller den liturgiske handlings personlige tiltale-karakter" (Thodberg (1969), 10-11). I denne fortolkning ligger der imidlertid, så vidt jeg kan se, to forskellige ansatser gemt, dvs. en fundamental uklarhed. Er meningen med at hævde, at det er pedanteri at flytte Fadervor hen efter overøsningen og døbeordene, at der ikke er et centrum i dåbsritualet, hvor Gud handler med mennesket og skænker det Helligånden; hvert led rummer hele dåbens betydning? Hvis der intet centrum er, intet før og intet efter, bliver det unægtelig pedanteri, hvor Fadervor er placeret i ritualet. Alligevel kan dette ikke være meningen, for hvis det på den anden side er bedst, at Fadervor er placeret i bønnens forgård som udtryk for menneskelig nød, fortvivlelse og gudsforladthed, forudsættes et før og efter alligevel, og denne forståelse af Thodbergs fortolkning passer med, at ritualets rækkefølge ifølge ham skulle være afgørende for Grundtvig, - men så må det alligevel være et væsentligt spørgsmål, om Fadervor er en forbøn for den udøbte eller et udtryk for den døbtes nye status.

På denne baggrund bliver det både nødvendigt at afklare, om Grundtvig regnede med et centrum i dåbsritualet, og om hans inspiration fra 1783-ritualet virkelig skal forstås som en altafgørende bundethed til rækkefølgen af led.

\section{Grundtvigs syn på dåbsritualets led}

Det er for længst godtgjort, at selv om Grundtvigs kirkelige anskuelse begyndte med et gennembrud i 1825, var den nærmere udformning noget, der fulgte i de følgende årtier, hvor hans forståelse af forsagelsen og trosbekendelsen som dåbspagt og som Herrens "Munds-Ord", meddelt disciplene i de 40 dage mellem opstandelse og himmelfart, blev til. ${ }^{19}$ Tilblivelsen af hele den mere komplicerede lære med en større, men afgrænset, gruppe af munds-ord er derimod ikke nærmere undersøgt i Grundtvigforskningen. Hvis man - i stedet for at søge et skjult anliggende - vil finde klare udsagn hos Grundtvig om forståelsen af dåbsritualets led, er det imidlertid denne lære, man må gå til.

19. Se redegørelsen i Henning Høirup, Grundtvigs Syn paa Tro og Erkendelse. Modsigelsens Grundsatning som teologisk Aksiom hos Grundtvig (København: Gyldendal 1949), 249-407, især 350-358. 
Ritualet fra 1783, som Grundtvig skulle have været "bundet" til, var opbygget sådan, at det pegede på døbeordene med vandoverøsningen som centrum, som selve den sakramentale handling. Det gjaldt bede-og-banke-bønnen, hvor der blev bedt om at få dåbens gave, det gjaldt lovprisningen "Lovet være Gud...", hvor den grammatiske tid i citatet fra 1 Pet 1,3 var ændret, idet grundtekstens aorist ( $\alpha v \alpha \gamma \varepsilon v v \eta ́ \sigma \alpha \varsigma)$ blev gengivet med en dansk fremtid ("vil igienføde"), fordi dåbskandidaten endnu ikke var døbt. Rettetheden mod centrum var endvidere tydelig, når der efter forsagelsen og trosbekendelsen blev spurgt: "Vil du paa denne Troe være døbt?” At selve døbeformelen "Jeg døber dig" var i nutid samtidig med, at der østes vand, angav centrum, at nu fandt dåben sted, og den efterfølgende brug af førnutid ("som dig nu haver igienfødt ... og haver forladt dig alle dine Synder") angav, at nu havde dåben fundet sted.

Uanset om Grundtvig virkelig var "bundet" til dette specifikke ritual, var det også hans mening, at døbeordene med vandoverøsningen var centrum. I tekster fra 1830 'erne betegnede han vandoverøsningen i Faderens, Sønnens og Helligåndens navn som "Daaben" eller "selve Daaben", mens forsagelsen og trosbekendelsen kaldtes dåbens vilkår, der var uadskilleligt forbundet med den. Døbeordene "i Faderens, Sønnens og Helligåndens navn” var ifølge Grundtvig indstiftelsesord, men de var utilstrækkelige, fordi de ikke kontekstualiserede, hvem der mentes med de tre navne, og også derfor var trosbekendelsen nødvendig for at præcisere, at det er det kristelige trossamfund, som man optages i. ${ }^{20}$ I senere tekster angav Grundtvig, at både dåbspagten og døbeordene er "Munds-Ord", dvs. ord, der efter hans opfattelse var udtalt af Jesus ved indstiftelsen af dåben og siden overleveret mundtligt i den kristne menighed og desuden stadig "talt til os". ${ }^{21}$ Desuden

20. Se fx Skal den Lutherske Reformation virkelig fortsettes? fra 1830-1831 (VU 3), 273: "hvem der vil skille Troes-Bekiendelsen fra Daaben, som dens Vilkaar, vil aabenbart skille de Døbte fra det vor Herres Jesu Christi Kirke-Samfund”; eller i Den danske Stats-Kirke upartisk betragtet fra 1834 (VU 3), 330: "og forandrede Man virkelig det Mindste ved Daabs-Pagten eller Daaben selv, da vilde jeg protestere". At døbeordene er indstiftelsesord og trosbekendelsen dåbspagt, fremgår fx af $\mathrm{Om}$ Daabs-Pagten fra 1832 (VU 3), 308: "naar vi saaledes indskrænke os til at kræve vor Daabs-Pagt ubrødelig holdt og Indstiftelsens Ord ved begge Naade-Midler nøiagtig fort og fulgt". Se Skal den Lutherske Reformation virkelig fortsattes? (VU 3), 271-272 om trosbekendelsen som identificerende, hvem de tre personer er.

21. Således Om Christendommens Sandhed - Om den sande Christendom, Efterskrift 1865 (US 4), 727: "Da nu Daaben og Nadveren, langtfra at ligge udenfor Fallesskabet i Menigheden, tvertimod ligger midt deri, som det nagelfaste Bohave (Inventarium) i Herrens Bedehus fra alle Folk (Traditio Dominica), og der til Herrens Munds-Ord ved hans egne Indstiftelser slet ikke regnes Andet end den falles Tiltale i Herrens Navn, som finder Sted fra Arildstid med Daabs-Pagten, Fadervor, Fredlysningen og de egenlige Indstiftelses-Ord ved begge de christelige Naademid- 
betegnede Grundtvig almindeligvis dåben som et bad, og han afveg ikke fra Luthers lære om vand som en nødvendig del af sakramentet. ${ }^{22}$ Af særlig interesse i denne sammenhæng er Grundtvigs afhandling Daaben efter Christi Indstiftelse fra 1840, der indgik i hans Kirkelige Oplysninger isar for Lutherske Christne. Afhandlingen tyder ikke på en særlig binding til netop 1783-ritualet. Grundtvig forestillede sig i stedet, at visse led i ritualet var indført af Jesus, og de var så afgørende, "at vi med det Væsenlige ved Daaben kun mene det, der nødvendigvis maa være indstiftet af Herren og derfor aldrig kan fattes,

$\overline{l e r " . ~ T i l s v a r e n d e ~ i ~ d e n ~ o v e r s i g t ~ o v e r ~ " m u n d s o r d e n e ", ~ s o m ~ G r u n d t v i g ~ b r a g t e ~ i ~ b r e-~}$ vet til Elise Stampe 18/7 1856, se Breve fra og til Grundtvig II: 1821-1872, red. Georg Christensen \& Stener Grundtvig (København: Gyldendalske Boghandel \& Nordisk Forlag 1926), 558-561, se også det senere brev til Stampe 14/8 1856, ibid., 570, eller brev til Vilhelm Birkedal 19/1 1855, ibid., 546-547. Vigtigheden af døbeordene ses også af, at treenighedslæren ifølge Grundtvig både skulle udledes fra dem og fra trosbekendelsen, se afhandlingen Den Guddommelige Treenighed fra 1858, der indgår i Den Christelige Børnelardom: "Ligesom vi nu, ved at udlede den christelige Treenigheds-Tanke udelukkende af Menighedens Fællesbekiendelse og Daabs-Ordet," ... (VU 6, 148). - Når Thomas Skat Rørdam, Grundtvig og Luthers lille Katekisme (Kjøbenhavn: G.E.C. Gad 1873), tenderede mod at sige, at Guds ord ved dåben for Grundtvig var dåbspagten snarere end døbeordet, var der således tale om en forenkling af Grundtvigs opfattelse.

22. Se Om den sande Christendom fra 1826, der blev genoptrykt i 1865 (US 4), 471: "Vandet i Daaben, Vinen og Brodet i Nadveren, er reen legemlige, haandgribelige Ting, og synes derfor langt mindre skikkede til Midler for Aanden. Nu sagde imidlertid dog Jesus: døber alle Folk i Navnet Faderens, Sønnens og den Hellig-Aands! Uden nogen bliver født paa Ny, kan han ikke see Guds Rige, uden nogen bliver født af Vand og Aand, kan han heller ikke indkomme i Guds Rige (Matth. 28. Joh. 3.), og det er da klart, baade at Jesus erklærede Vandet i Daaben for et aandeligt Middel, og Vand-Daaben for en uadskillelig Deel af den aandelige Igienfødelse, uden hvilken man ei kunde blive et Guds Barn paa Ny"; jf. også ibid., 487. Se videre hans prædikener 1839-1842 ved Jette Holm et al. (red.), Grundtvig: Predikener $i$ Vartov, bd. 1: 1839-40, Fra 2. søndag efter trinitatis 1839 (Grundtvigs indsattelse $i$ Vartov); bd. 2: Kirkearret 1840-41; bd. 3: Kirkearret 1841-42; bd. 4: Thodberg, Indledning og kommentar til Grundtvigs predikener i Vartov 1839-42 (bind 1, 2 og 3) (København: Forlaget Vartov 2003): bd. 1, 181, 251, 411; bd. 2, 326-327. Jf. også Daaben efter Christi Indstiftelse fra 1840 (US 8), 423, der til "Daabens Vesen efter Christi Indstiftelse" bl.a. fremhæver "Pagtens og Optagelsens Ord", samt vandet, der ikke er det væsentligste, men ikke må glemmes eller foragtes. - Daaben efter Christi Indstiftelse er fra 1840, men udkom i begyndelsen af januar 1841, se Steen Johansen, Bibliografi over N.F.S. Grundtvigs Skrifter II: 1837-1849 (København: Gyldendalske Boghandel \& Nordisk Forlag 1950), 176 (nr. 687). I afhandlingen De Syv sakramenter, der indgår i Den Christelige Børnelardom, fremhæver Grundtvig (VU 6, 68-69), at "Herrens Indstiftelser til det faldne Menneskes Opreisning maatte kun have baade synlige og usynlige Bestanddele, for at omfatte hele Mennesket, der jo er en Forening af det Synlige med det Usynlige, og de synlige Ting i Daaben og Nadveren er derfor ikke Tegn paa det Usynlige i dem, men hører ligesaa virkelig til Tingen, til det guddommelige Lage-Middel i sin Heelhed, som Legemet hører til Menneskeligheden.” Dette sted fremhæves med rette i Bjerg (2002), 53-54. 
hvor Naademidlet fuldelig skal træde i Kraft” (US 8, 425). Ved siden af døbeordene insisterede Grundtvig i denne afhandling på, at dåbspagten, som den fandtes i den lutherske statskirke, hørte med som dåbens vilkår, idet tro og dåb hører sammen, men han kritiserede, at trosbekendelsens ordlyd i alterbogen afveg fra det latinske ritual; afvigelserne burde rettes, da intet ord er ubetydeligt, når alle udtryk er Herrens egne (US 8, 417-423). Helt præcist pegede Grundtvig på "Feil" i tredje trosartikel:

en saadan Feil er, desværre, for længe siden indløbet i vor Alterbog, hvor et af Spørgsmaalene findes saaledes: troer du paa den Hellig-Aand, en hellig christelig Kirke at vare, som er hellige Menneskers Samfund, Syndernes Forladelse, Legemets Opstandelse og efter Døden det evige Liv? Naar vi nemlig sammenligne denne Opskrift med den Latinske i Roms Alterbog, som den skulde svare til, da vi beviislig har faaet Daaben fra den Romerske Kirke-Stat, da sees det, at vore Fædre har gjort flere egenmægtige Forandringer, sat "christelig" istedenfor "almindelig" Kirke, indskudt Ordene "at være" og "som er," sat "Legemets" istedenfor "Kiødets" Opstandelse, og endelig indskudt "efter Døden" foran "det evige Liv" (US 8, 419-420).

Når der ses bort fra ortografiske ændringer, svarer citatet her til teksten i Forordnet Alter-Bog (1812), 246, men når Grundtvig siger, at "fejlen" for længe siden er indløbet i den danske alterbog, har han muligvis også sammenlignet med ældre alterbøger. ${ }^{23}$ "Roms Alterbog", som Grundtvig her inddrager, må nu være Rituale Romanum, der i 1614 blev publiceret af pave Paul V som det første officielle katolske dåbsritual. Ved sin død i 1872 var Grundtvig i besiddelse af en udgave fra $1665,{ }^{24}$ og i dette ritual lyder tredje trosartikel netop: "Credis in Spiritum sanctum, sanctam Ecclesiam Catholicam, Sanc-

23. Det fremgår af Fortegnelse over N. F. S. Grundtvigs Bibliothek (1873), 86-87, at Grundtvig ejede to udgaver af Palladius' alterbog (nr. 2164-65 fra 1611 og 1666), et udtog af alterbogen fra 1801 (nr. 2168), alterbogen 1812 (nr. 2166, jf. her note 7) og 1857 (nr. 2167), samt to eksemplarer af kirkeritualet fra 1761 (nr. 2169-70), og desuden C.T. Engelstoft, Alterbogens og Kirkeritualets Historie i Danmark (Kjøbenhavn: C.A. Reitzels Forlag 1840) (nr. 2163). De fleste af de "fejl”, som Grundtvig ankede over, findes da også hos Palladius ("christelig", "som er", "legemets" og "efter døden”). Derimod var flere af disse strøget i Forordnet Alter-Bog for Danmark (Kjøbenhavn: Den Gyldendalske Boghandlings Forlag 1830), 247 (her mangler nemlig "at være", "som er" og "efter døden”), men denne alterbog nævner Grundtvig ikke. 24. Dette fremgår af Fortegnelse over N. F. S. Grundtvigs Bibliothek (1873), 91 (nr. 2212): "Rituale Romanum Pauli V pontificis jussu editum. Edit. noviss. Lutetiæ Paris. 1665.” Denne udgave har dog ikke været tilgængelig for mig, men en lidt senere, som jeg i det følgende citerer fra: Rituale Romanum, Pauli V. Pontificis Maximi jussu editum, Editio novissima (Lyon 1689). 
torum communionem, remissionem peccatorum, carnis resurrectionem, vitam æternam ?" (Rituale Romanum (1689), 32). Grundtvig har ikke været klar over, at liturgiske tekster havde en variabel karakter i ældre tid, som det først blev muligt at afskaffe med bogtrykkerkunsten, og han har heller ikke vidst, at der på reformationstiden var andre latinske dåbsritualer i omløb, og at de danske alterbøger ikke gik tilbage til teksten i Rituale Romanum. I de latinske dåbsritualer fra senmiddelalderen og begyndelsen af 1500-tallet genfindes netop en af de "fejl” i tredje trosartikel, som Grundtvig protesterede imod: “... carnis resurrectionem et vitam eternam post mortem". ${ }^{25}$ At Grundtvig ikke kendte til disse ting, kan dog vanskeligt bebrejdes ham, for på denne tid var man endnu ikke begyndt at udgive middelalderlige dåbsritualer af liturgihistorisk interesse.

I Daaben efter Christi Indstiftelse sammenlignede Grundtvig imidlertid også med Luthers "Døbe-Bog", altså hans Taufbüchlein. Grundtvig skrev:

Og hvad nu Feilene i vor Alterbog angaaer, da skal det ikke blot til Luthers Ære, men især til Menighedens Oplysning, bemærkes, at kun en Eneste af dem findes i hans "Døbe-Bog," saa Resten har indsneget sig hos os selv, deels af blot Skiødesløshed og deels af en barnagtig Lyst til at giøre tydelig hvad vi ei forstod. Hos Luther lyder nemlig det tredie Spørgsmaal om Troen som saa: troer du paa den Hellig-Aand, en hellig, christelig Kirke, de Helliges Samfund, Syndernes Forladelse, Kiødets Opstandelse og det evige Liv? Det er altsaa kun Ordet "christelig" istedenfor "almindelig", Luther har at svare for, ...

Og i en note tilføjede Grundtvig den tyske tekst, som han oversatte fra: "Glaubest du an den heiligen Geist, eine heilige Christliche Kirche, die Gemeinschaft der Heiligen, Vergebung der Sünden, Auferstehung des Fleisches, und ein ewiges Leben?” (US 8, 427). Problemet er her, hvilken (dårlig) udgave af Luthers Taufbüchlein Grundtvig i dette tilfælde benyttede, for også hos Luther rummede tredje trosartikel (både i Taufbüchlein fra 1523 og 1526) leddet "efter døden". ${ }^{26}$

\footnotetext{
25. Se $\mathrm{fx}$ J. Freisen (red.), Manuale Curatorum secundum usum ecclesie Rosckildensis. Katholisches Ritualbuch der dänischen Diözese Roeskilde im Mittelalter (Paderborn: Jungfermannschen Buchhandlung 1898), 7; idem (red.), Liber Agendarum ecclesie et diocesis Sleszwicensis. Katholisches Ritualbuch der Diözese Schleswig im Mittelalter (Paderborn: Jungfermannschen Buchhandlung 1898), 48. Jeg skylder Villadsen disse oplysninger sammen med den vigtige indsigt, at Grundtvig må sigte til Rituale Romanum, når han mener, at den "rigtige" apostolske trosbekendelse er uden leddet "efter døden".

26. Ved sin død i 1872 var Grundtvig i besiddelse af J.G. Walchs Lutherudgave i 24 bind (Halle 1739-50), som det fremgår af Fortegnelse over N. F. S. Grundtvigs Biblio-
} 
Grundtvig beskæftigede sig også med de andre led i dåbsritualet i Daaben efter Christi Indstiftelse. Han mente således, at "den høitidelige Erklæring" "Den almægtige Gud, vor Herres Jesu Christi Fader, som dig nu haver gjenfødt" osv. var "et Ord af Herren", der hører til "det væsenlige ved Daaben", blot kritiserede han senere ændringer i ordlyden i forhold til det romerske ritual, og særligt at man havde ændret den tidligere formulering "Han salve dig Selv med Frelsens Olie i den samme Jesus Christus vor Herre" til "Han styrke dig med sin Naade" (US 8, 423-424). ${ }^{27}$ I Grundtvigs senere opregninger af "mundsordene" mangler denne "Erklæring" dog oftest. Det er i øvrigt værd at bemærke, at Luther netop havde fastholdt ordene om salvelsen i 1523-udgaven af Taufbüchlein, men afskaffet dem i 1526.

Endvidere mente Grundtvig i denne tekst, at fredlysningen efter dåben "er et Ord af Herrens egen Mund"; det fremgår af Joh 20,19, men at Jesus også har forordnet dette ord ved indstiftelsen af dåben, følger af, at Jesus må have villet give sine døbte sin velsignelse, og fredlysningen var "lige til Reformationen ... Kirkens eneste Udtryk for 'Herrens Velsignelse”, hvor den ved den øvrige gudstjeneste blev erstattet med den aronitiske velsignelse (US 8, 424).

I Daaben efter Christi Indstiftelse var Grundtvig nu i tvivl om, hvor han skulle "trække en skarp Grændse-Linie" mellem pdes. de nævnte mundsord sammen med vandet og pdas. de øvrige dele af dåbsritualet, enten de var i brug eller engang havde indgået i det. Nogle af disse øvrige dele kunne ikke opgives, nemlig dem "som med præg af den Hellig-Aand har gjennemlevet Kirken og naaede til os", og til disse hører Fadervor og korstegnelsen. ${ }^{28}$ Endnu i 1840 var Grundtvig altså i tvivl, om Fadervor hørte med til Jesu indstiftelse af dåben, og det

thek (1873), 23-24 (nr. 736-59). Alligevel kan han ikke have benyttet denne udgave i 1840 , for her lyder tredje trosartikel i begge Luthers døbebøger (bind 10 (1744), sp. 2632 og 2637): "Gläubest du an den Heiligen Geist, eine heilige Christliche Kirche, Gemeine der Heiligen, Vergebung der Sünden, Auferstehung des Fleisches, und nach dem Tode ein ewiges Leben?"

27. Sml. Rituale Romanum (1689), 34: "ipse te liniat Chrismate salutis in eodem Christo Iesu Domino nostro".

28. Daaben efter Christi Indstiftelse (US 8), 425. Grundtvig (US 8, 425-426) diskuterede også de øvrige "skikke eller billedlige Handlinger, som følge med den Romerske Daab” (dvs. djævlebesværgelsen, salvelsen, dåbshuen og dåbslyset); hans forhold til dem var ambivalent. Besværgelsen, som først var afskaffet 1783, var den anstødeligste, medens de andre egentlig ikke var ukristelige, ja, man kunne endog have brugt dem til at "gjøre en langt bedre Indledning til Daabs-Handlingen end enten Biskop Balles eller selv Morten Luthers," men alligevel gjorde Luther og de danske reformatorer ret $\mathrm{i}$ at afskaffe dem, fordi de overskyggede selve dåben. Det er værd at bemærke, at Luther netop havde salvelsen, dåbshuen og dåbslyset med $\mathrm{i}$ Taufbüchlein fra 1523, men afskaffede dem i 1526. 
viser også, at læren om mundsordene ikke var færdigdannet på dette tidspunkt.

I hvert fald var 1783-ritualet ikke af afgørende betydning for Grundtvig i 1840; primært havde det derimod betydning, om ritualets led stammede fra Jesu indstiftelse, og sekundært om de var gamle og kristelige. Grundtvig ville næppe heller have accepteret en binding til ritualet fra 1783, da et af hans motiver til at udvikle den kirkelige anskuelse var ønsket om at finde et grundlag, der udtrykte troens identitet gennem hele historien, som fremhævet af Høirup $(1949,352)$.

Springer vi fra Daaben efter Christi Indstiftelse fra 1840 frem til artiklen Den Christelige Børnelardom fra 1855, der i 1868 kom til at indgå i bogen Den Christelige Børnelardom, finder vi en mere udviklet lære om dåbens væsentlige led. Betydningen af sakramentet er,

at Daaben i Faderens, Sønnens og den Helligaands Navn er den eneste Optagelse, med det Vidnesbyrd, at denne Daab skeer ikke blot med Vand, men med "Vand og Aand," og er derfor ingen blot saakaldt Kirkeskik (Ceremoni) men er et himmelsk Gienfodelses-Bad, hvorved den Helligaand $\mathrm{i}$ Vorherres Jesu Christi Navn skiænker os Synds-Forladelse og himmelsk Børne-Ret med det evige Livs Haab.

Derefter søger Grundtvig nøje at skelne mellem betydningen af de vigtigste led ved at sige, hvad de "lærer os", og her bruger han det særlige navneord "Døbelse" om det egentlige nådemiddel, vandoverøsningen i Faderens, Sønnens og Helligåndens navn, som "lærer os, paa hvad Maade og ved hvilket Middel et Menneske optages i Christi Menighed og bliver en Christen". Han fortsætter:

Herrens Velsignelse ved Daaben "Fred være med dig!" lærer os at der ved at blive en Christen vindes Fred med Gud og Synds-Forladelse, og ligesom Herrens Bøn: Fadervor, der med Daaben er lagt i hele Christi Menigheds Mund, og ved Daaben lægges i hver enkelt Christens Mund, lærer os, at Mennesket ved at blive Christen, bliver et Guds Barn, saaledes lærer Daabs-Pagten os baade, hvad det er for en Fader, hvad det er for en Søn, og hvad det er for en Helligaand, i hvis Navn et Menneske døbes til en Christen, og lærer i det hele, hvad der udkraves af ethvert Menneske, som ved Daaben efter Herrens Indstiftelse vil optages i Christi Menighed, ... (VU 6, 4-5)

Det er her klart, at Grundtvig ikke mente, som ellers hævdet af Thodberg, at hvert eneste led af ritualet hver for sig rummede hele dåbens 
betydning. Hver for sig udtrykker leddene forskellige nuancer og konsekvenser af dåben.

Grundtvig nævner på dette sted leddene i flæng og lægger ikke nogen vægt på deres rækkefølge. At Fadervor bliver lagt i munden "ved" og "med" dåben, siger i sig selv heller ikke noget om Fadervors præcise plads i ritualet, men kun om denne bøns uadskillelige tilknytning til dåben. Alligevel synes Grundtvig her også at sige noget mere, for når han anfører, at det er ved døbelsen, at mennesket bliver en kristen, medens modtagelsen af Fadervor lærer os, at ved at blive kristen bliver man et Guds barn, bliver Fadervor jo en tydeliggørelse eller konsekvens af selve døbelsen. Der er derfor her heller intet om Fadervor som en forbøn i den menneskelige nød, fortvivlelse og gudsforladthed; Fadervor er en følge af, at den døbte nu er kristen; det er blevet Guds barn og har dermed Gud som fader.

Året efter (18/7 1856) skrev Grundtvig et brev til sin tidligere konfirmand, Elise Stampe (1824-1883), hvori der ligesom i Daaben efter Christi Indstiftelse gives et bredere billede af hans syn på dåbsritualet (Christensen og Grundtvig (1926), 558-561). Supplerende oplysninger findes i det følgende brev til Stampe fra 1/8 1856 (Christensen og Grundtvig (1926), 564-567). I det første brev forklarede Grundtvig, at årsagen til hans brev var et tidligere møde med Stampe:

Da jeg senest havde den Fornøielse at være paa Nysø og vi talde et Par Ord sammen om "Daaben" da yttrede De Lyst til at vide, hvormange af de Ord, vi hos os bruge ved Saligheds Midlet, der maa tages som Guds Ord af Vorherres egen Mund, og hvor meget vi af det Øvrige har tilfælles med den ældre Menighed, ...

Grundtvig mente også her, at dåben både drejer sig om det udvortes (vandet) og det indvortes (ordet), og at "de Ord, hvori Aanden bekiender Herren, aabenbarer Troen og virker Frelsen” må være ord, som Jesus har sagt til apostlene. Deraf fulgte, at både trosbekendelsen og døbeordene måtte være Jesu munds-ord. "Kun Saameget tør vi kalde klart Vorherres egne Ord ved Daaben", hævdede Grundtvig, men skrev alligevel i det følgende, at vi aldrig kan tvivle om, at Jesus også har tilføjet Fadervor og fredlysningen, da han indstiftede dåben.

Derefter gik Grundtvig over til spørgsmålet om, hvor meget af "Forskriften om Daaben i vor Alterbog", der er fælles "med den ældre Menighed": "Hvad saa i Øvrigt Forskriften om Daaben i vor Alterbog angaaer, da er den lange Indledning af tunge Bibelsprog ikke ældre end Biskop Balles Tid, da vi før fra gammel Tid havde en kort Indledning, der efter apostolisk Anviisning fremstillede Israeliternes Overgang i det røde Hav, som den christelige Daabs Forbillede, som 
en Overgang, nemlig fra de Dødes Rige til de Levendes Land." I et senere brev til Stampe 14/8 1856 (Christensen og Grundtvig (1926), 571), skrev han tilsvarende: "Da mine Bøger er i Uorden, kan jeg i dag ikke finde det gamle Ritual, men det mærkelige ved Indledningen til Daaben var laant af 1 Cor X. 1. 2. hvor Apostelen udtrykkelig nævner Overgangen af det røde Hav med Moses i Spidsen, som den christelige Daabs Forbillede." Grundtvig sigtede her til Luthers "syndflodsbøn", der jo kombinerede hentydninger til 1 Pet 3,20-21 og 1 Kor 10,1-7, og som han tydeligt foretrak. Fra 1556 (Peder Palladius' alterbog) og helt til 1783 havde denne bøn i dansk oversættelse indgået i dåbsritualet. Grundtvig sagde ikke noget klart om denne bøns oprindelse, måske fordi han vidste, at den ikke forekom i Rituale Romanum, som han havde konsulteret i 1840. Luther havde dog angivet i sin første Taufbüchlein fra 1523, at dåbsritualet var oversat fra latin til tysk, og dette kan have givet Grundtvig en fornemmelse af, at bønnen var af gammel oprindelse. Bønnens oprindelse er stadig omstridt:

\begin{abstract}
Luthers Sintflutgebet ist ein "liturgischen Rätsel”. Auf der einen Seite ist es ganz durchtränkt von altkirchlichen Symbolen und spätmittelalterlichen Anklängen, auf der anderen Seite finden sich viele wörtliche Parallelen gerade in Luthers Schriften zwischen 1519 und 1523. So streiten sich die Forscher, ob der Reformator auch hier lediglich ein altkirchliches oder auch spätmittelalterliches Gebet übersetzt habe oder es in engem Anschluß an die traditionelle Gedanken- und Bilderwelt eigenständig geschaffen habe. ${ }^{29}$
\end{abstract}

Grundtvigs interesse for den typologiske sammenhæng mellem det Gamle Testamente og dåben tyder på, at den frelseshistoriske sammenhæng mellem de to pagter var af særlig vigtighed for ham, og dette viser sig i fortsættelsen i brevet til Stampe fra 18/7 1856, der beskæftiger sig med den såkaldte bede- og bankebøn (Christensen og Grundtvig (1926), 560):

29. Albrecht Peters, Kommentar zu Luthers Katechismen 5: Die Beichte. die Haustafel. Das Traubüchlein. Das Taufbüchlein (Vandenhoeck \& Ruprecht: Göttingen 1994), 163-172, citat 163-164. Se videre Kent Jorgen Burreson, The Saving Flood. The Medieval Origins, Historical Development, and Theological Import of the Sixteenth Century Lutheran Baptismal Rites. A Dissertation Submitted to the Graduate School of the University of Notre Dame In Partial Fulfillment of the Requirements for the Degree of Doctor of Philosophy, Department of Theology, Notre Dame, Indiana 2002. Jf. også Thodberg (1999), 66 = idem (2017), 77-78. 
Bønnen før Daaben, om "den evige Velsignelse i det himmelske Bad” er ældgammel og ventelig apostolisk, thi ligesom Kiernen i den gamle Pagt med Abraham var Løftet "om Sæden” i hvem alle Slægter skulde velsignes, saaledes er Kiernen i den ny Pagt med de Troende, denne Sæd selv med Velsignelsen.

Grundtvig mente, at bede- og bankebønnen var ældgammel, idet han drog historiske slutninger fra den særlige teologiske eller religiøse betydning, som han fandt i ritualet. Bønnens latinske forlæg, "Deus immortale praesidium", indgår blot ikke i barnedåbsritualet $\mathrm{i}$ Rituale Romanum, men Grundtvig må have været på det rene med, at bønnen var ældre end Luther: Dels angav Luther selv i sin første Taufbüchlein fra 1523, at han oversatte fra latin til tysk, dels indgik "Deus immortale praesidium" i det katolske voksendåbsritual (se Rituale Romanum (1689), 56), og det kan Grundtvig have læst. ${ }^{30}$ Under alle omstændigheder er det vigtigt at bemærke, at Grundtvig altså ikke forstod bede- og bankebønnens henvisning til velsignelsen ud fra 1783-ritualets interne sammenhæng, som antaget i Thodberg (1969), 32-38, men i stedet ud fra den større bibelsk-frelseshistoriske sammenhæng, nærmere bestemt forjættelsen til Abraham, primært formodentlig Gal 3,8-9,14, sml. fjernere Gen 12,2-3; 18,18; 22,18; 26,4; 28,14; ApG 3,25. ${ }^{31}$

Ejendommeligt er det, at Grundtvig i 1856 helt klart sammenblandede erklæringen "Den almægtigste Gud, vor Herres Jesu Christi

30. Bede- og bankebønnen var i Luthers 1526-udgave af hans Taufbüchlein en forkortelse af bønnen "O Gott, du unsterblicher Trost"/"Deus immortale praesidium" i 1523-udgaven, se Thodberg (1999), 59, 61, 66 = idem (2017), 69-71, 77; Peters (1994), 158, 162-163.

31. Grundtvig må længe have næret den samme interesse for 1 Kor 10,1-7 og forjættelsen om Abrahams sæd i sammenhæng med dåben, for den findes allerede i hans Christelige Predikener eller Søndags-Bog II (I-III, Kiøbenhavn: Wahlske Boghandlings Forlag 1827-1830), 204-222; her nogle eksempler: "Israels Historie, heel og holden, er os en stor prophetisk Bog, hvori vi speide Guds Førelser med Christenheden til Verdens Ende!” (210). "Med Apostelen Paulus, med Morten Luther, og med alle vore Christelige Fædre, betragte vi da hele det Gamle Testamente, som et Forbillede, og en Spaadom, og en Gaade, der i det Ny har fundet sin Gienstand, sin Løsning, og Opfyldelse” ... "fremfor alt betragte vi Israels Vandring, fra Ægypten til det forjættede Land, som en af Herrens Aand ved Apostlerne forklaret historisk Prophetie, hvori hele Christendommens Historie speiler sig!” (211). Og en klar hentydning til syndflodsbønnen: "Sandelig, det var da ingen Misforstand, som endog Christne nu enstund har meent, men ret Forstand, som den levende udspringer af christelig Tro, at vore Fædre over Daaben ihukom Israels Vandring med tørre Fødder giennem det røde Hav som et Forbillede" (213). Velsignelsen i Abrahams sæd nævnes 211, 214. - Sammenhængen mellem velsignelsen til "Sæden" i den gamle pagt og dåben i den nye er fx også et tema i GSV 5, No. 176 ("Velsignelsen" fra 1862). 
Fader, som dig nu haver igienfødt" osv., der fulgte efter dåben, med lovprisningen af Gud Fader før dåben - en fejl der kaster et ironisk skær over Thodbergs forestilling om den afgørende betydning for Grundtvig af 1783-ritualets rækkefølge:

Endelig er ogsaa Taksigelsen og Ønsket efter Daaben "Lovet være Gud, Vorherres Jesu Christi Fader" o.s.v. ældgammel, kun har vi udeladt, hvad vi skulde beholdt i Slutningen: Han salve dig med Frelsens Olie i den samme Christus Jesus, Vorherre, til det evige Liv!

Denne lovprisning var først kommet ind i det danske dåbsritual i 1783 som en kombination af 1 Pet 1,3 og Rom 6,4, og den kom før dåben i ritualet. Derimod fulgte erklæringen "Den almægtigste Gud" osv. efter dåben, og det var den, der i det romerske ritual havde mundet ud i ordene om salvelse, som Grundtvig også i 1840 havde hævdet ikke burde have været fjernet. Enten skyldes sammenblandingen simpelthen, at Grundtvig havde glemt ritualets rækkefølge, eller også var den forårsaget af, at han ønskede at flytte lovprisningen hen efter dåben, så den ville komme til at stå i nærheden af erklæringen. 1783-ritualet havde jo ændret udsagnsordet i 1 Pet 1,3 til fremtid, fordi dåbskandidaten end nu ikke var døbt: "Lovet være Gud og vor Herres Jesu Christi Fader, som efter sin store Barmhiertighed vil igienføde dig til et levende Haab, formedelst Jesu Christi Opstandelse fra de Døde”. Hvis Grundtvig uden nærmere forklaring ville flytte denne lovprisning, kunne det skyldes en modvilje mod at ændre udsagnsordets tid i forhold til 1 Pet $1,3 .^{32}$

I indledningen til det næste brev til Stampe fra 1/8 1856 beskæftigede Grundtvig sig med nogle led af dåbsritualet, som han tydeligvis ikke havde husket at inddrage i sit første brev. Han henviste til, at han i artiklen Forsagelsen i Daabs-Pagten fra samme år (der i 1868 kom til at indgå i Den Christelige Børnelardom) havde redegjort for, at forsagelsen er en del af dåbspagten. Han formodede imidlertid også, at korstegnelsen hørte til selve Jesu indstiftelse af dåben; det havde

32. Imod denne forklaring kunne det dog tale, at Grundtvig selv nogle få år før, i 1853, havde ændret udsagnsordets tid, dog ikke til fremtid, men til nutid, nemlig $\mathrm{i}$ en håndskrevet oversættelse af 1 Petersbrev, der for nylig blev udgivet: "Høilovet være Vorherres Jesu Christi Gud og Fader, som efter sin store Barmhjertighed gienføder os til det ved Jesu Christi Opstandelse fra de Døde levende Haab”, og tilsvarende andre steder, se Nypagts-Bogen. Grundtvigs nytestamentlige oversattelser, red. Jette Holm et al., Skrifter udgivet af Grundtvig-Selskabet XLI, Palmeserien 11 (København: Fønix 2018), 25, sml. videre 243, 273-274, hvor der som forklaring foreslås: "Ved at vælge præsensformer udvider Grundtvig pronominet 'os', så det kommer til at omfatte alle dem, der til alle tider genfødes og velsignes.” Det er dog værd at huske, at bibeloversættelse og ritual er to forskellige sammenhænge. 
han tidligt både sluttet af, at den havde været "brugt ved Daaben fra Arildstid", selv om den "misbruges saaledes af Katholikerne med idelig Gientagelse ved Daaben", og af at han så en hentydning til korstegnelsen i "Menneskens Søns Tegn" (Matt 24,30), men senere var det gået op for ham, "at Korsets Tegn ved Daaben, med det christelige Ord, som erklærer det for Menneske-Sønnens, den korsfæstede Frelsers Tegn, maa igrunden høre ligesaa nødvendig til Forsagelsen, som Døbelsen til Troes-Bekiendelsen". Denne betragtning, der igen viser, hvordan Grundtvig sluttede til historisk oprindelse fra den religiøse betydning, som han selv fandt i ritualets led, er imidlertid interessant, fordi den viser, at Grundtvig ikke søgte dåbens betydning i 1783-ritualets disposition eller rækkefølge af led, hvor korstegnelsen og forsagelsen var adskilte fra hinanden med mange led. Da Grundtvig var opmærksom på katolikkernes brug af korstegnelsen flere steder i dåbsritualet, er det derfor muligt, at han tænkte på, at der i det romerske ritual indgik en korstegnelse sammen med salvelsen umiddelbart efter forsagelsen (jf. Rituale Romanum (1689), 32), men det er i hvert fald klart, at Grundtvig mener at finde en oprindelig nærmest sakramental sammenhæng mellem korstegnelse og forsagelse, der forelå i fordrejet form i den ældre forbindelse mellem korstegnelse og exorcisme. ${ }^{33}$

Samme brev giver endnu et eksempel på Grundtvigs interesse for det romerske ritual: "Det deilige Ord: Gud bevare Din Indgang og Udgang er taget af en Davidssalme og lagt til af os, men før hedd det: gak ind i Guds Tempel, at du kan have Deel med Christus til det evige Liv!" Her sigtede Grundtvig jo til det romerske ritual, ${ }^{34}$ men var samtidig også interesseret $\mathrm{i}$, at det lutherske ritual citerede SI 121,8. Formodentlig foretrak Grundtvig det romerske ritual, fordi det ligesom syndflodsbønnen udtrykte, at dåben var en overgang fra død til liv. Derfor kan Grundtvigs henvisning til Sl 121,8 også have rummet en interesse for bibelordets virkelige ordlyd (Gud bevare din udgang og indgang), som jo var forandret i det daværende dåbsritual. Hvis det er rigtigt, ville denne interesse passe med den senere tilbageføring til Sl 121,8's ordlyd i Fengers ritualforslag, for Fengers begrundelse ((1874), 9: "fordi vi ved Daaben udgaae fra det blotte Verdensliv og indgaae til Livet i Guds Rige")) er helt i tråd med Grundtvig, der

33. Grundtvig skrev (i brevet til Stampe fra 1/8 1856), "at den papistiske Misbrug af det bare og blotte Tegn til Beskærmelse fra den Onde, er kun, som det meste Papisterie en kiødelig Brug af et aandeligt Middel, som virkelig, naar det bruges aandelig med Ordet, er et 'pak dig Satan!' fra Vorherre, der lægger Kraft i vor Forsagelse, der i sig selv vilde være afmægtig."

34. Sml. Rituale Romanum (1689), 29: "Ingredere in templum Dei, ut habeas partem cum Christo in vitam æternam.” 
netop sympatiserede med, at syndflodsbønnen og stedet om templet i romerske ritual udtrykte, at dåben var en overgang fra død til liv (jeg vil i en anden sammenhæng behandle spørgsmålet om Grundtvigs andel i Fengers forslag til dåbsritual).

\section{Sammenfatning}

Sammenfattende kan det siges, at selv om Grundtvigs udgangspunkt var det samtidige dåbsritual, forholdt han sig i de her undersøgte tekster selvstændigt og kritisk til 1783-ritualets led og deres rækkefølge; spørgsmålet var for ham, hvad der var det oprindelige ritual. Han stod fast på, at selve frelsesmidlet var vandoverøsningen med døbeordene, men han antog, at dette centrum fra begyndelsen måtte have været forbundet med andre væsentlige dele af ritualet, fordi de tilførte det en afgørende religiøs eller teologisk betydning: På grundlag af denne afgørende betydning mente Grundtvig at kunne drage slutninger om, at bestemte led stammede fra Jesu indstiftelse. Om andre mindre vigtige, men teologisk rigtige dele af ritualet tænkte han tilsvarende, at de måtte stamme fra apostlene. Det er et gennemgånde træk i de undersøgte tekster, at når Grundtvig genkendte et motiv fra Bibelen i ritualet, så opnåede han et støtteargument for ritualets ælde: Når Bibelen forbinder tro og dåb, må trosbekendelsen være oprindelig, velsignelsen i bede- og bankebønnen må være ældgammel, fordi kernen i kristendommen er opfyldelsen af forjættelsen til Abraham om velsignelse i hans sæd osv. Grundtvig havde også kendskab til det romerske ritual, Luthers Taufbüchlein og udviklingen af det danske dåbsritual efter Reformationen, og på dette grundlag var han kritisk over for forandringer, også forandringer der allerede var foretaget $\mathrm{i}$ dåbsritualet før hans egen tid.

På baggrund af denne analyse af Grundtvigs forståelse af dåbsritualets led og og indbyrdes rækkefølge, er der skabt det fornødne grundlag for den følgende artikels nærmere undersøgelse af Grundtvigs syn på Fadervors rolle og placering i dåben og betydningen af begrebet "Guds børn". 